\title{
Prediction of Cardiovascular Risk Comparing Algorithmic Models and Cardiac Risk Factors in Plwha on Art With Overwiegth/ Obesity
}

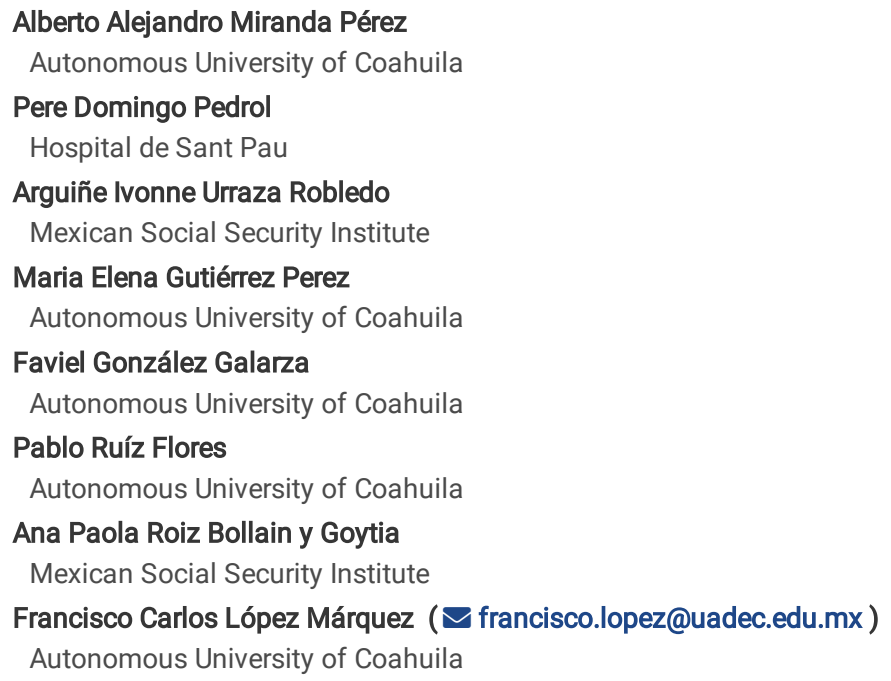




\section{Abstract}

Objective: The aim of this study was in seropositive subjects from Northern Mexico undergoing cART.

Methods: This study included 186 PLWH under CART. The variables analyzed were CD4+ count, viral load, lipid profile, glucose, insulin resistance, anthropometric measures, family history of hypertension and cardiovascular disease, years of treatment and cART scheme. In this study, we used two wellestablished algorithmic models D:A:D (5-year period) and Framingham (10-year period) for assessing cardiovascular risk.

Results: In our study, $51.3 \%$ of the PLWH had arterial hypertension; most of the subjects were diagnosed with overweight, hypertriglyceridemia and metabolic syndrome, which are factors that increase the risk of cardiovascular disease. After the assessment with the Framingham model, risk was considered as low, while for the D:A:D model was moderate for this population.

Conclusions: PLWH receiving cART present factors that may increase the risk of early heart disease including hypercholesterolemia, hypertriglyceridemia, smoking and age. Although risk was low/moderate after the assessment, it is important to consider other factors such as age of the subjects, overweight/obesity, smoking or coinfections, in addition to years of exposure to cART, which could increase the rate of heart disease.

\section{Introduction}

The successful use of combination antiretroviral therapy (cART) has resulted in an increase in life expectancy for people living with human immunodeficiency virus (HIV) infection $(1,2)$. Over the last years, there has been a shift in HIV-related health complications, changing from opportunistic infections related to the immunodeficiency to other problems related to the use of cART (e.g., drug toxicity or resistance to antiretrovirals) and, more recently, to other diseases which are not directly related to the acquired immune deficiency syndrome (AIDS) (3-6). Moreover, several conditions associated with aging and metabolic disorders have become more frequent in HIV positive populations, including hypertension, type 2 diabetes (T2D), dyslipidemia, obesity, among many others. These factors, combined with other well-known elements such as age, sex, smoking, CD4+ counting and viral load, are also considered in assessing cardiovascular problems in individuals with HIV (7-9).

Traditional cardiovascular risk assessment algorithms have been developed for the general population, such as the Framingham Risk Score (FRS), which has also been established as a good predictor in HIV-infected patients [10-12]). Additionally, several studies have compared the usefulness of different algorithms to estimate the risk of cardiovascular disease (CVD) in HIV-infected populations including The Prospective Cardiovascular Munster (PROCAM), the equations for Systematic Evaluation of the Coronary Risk (SCORE) (12-16), and the Data-collection on Adverse Effects of Anti-HIV Drugs (D:A:D), which comprises the evaluation of the effect of antiretroviral drugs on cardiovascular risk (17-20). HIV-infected patients face an increased risk of cardiovascular disease. Multiple observational cohort studies have shown high rates of acute myocardial infarction (AMI) or coronary heart disease (CHD) in patients infected with HIV compared to non-HIV subjects, with a relative risk of $\sim 1.5-2$ times higher $(7,21-26)$. Presently, there is only one cardiovascular risk score specifically developed for HIV-infected patients (27). This algorithm is based on the results of a large multi-center cohort study (The Data Collection on Adverse Effects on Anti-HIV Drugs Cohort-DAD), conducted mainly in Europe and North America. The D:A:D equation takes antiretroviral drug exposure into account as a potential risk factor for cardiovascular events. To date, the D:A:D risk equation has only been applied for CVD risk estimation(28).

The aim of this study was to evaluate risk factors that may increase cardiovascular risk/development of heart disease and to estimate the cardiovascular risk at 5 and 10 years in seropositive subjects from the Comarca Lagunera of Northern Mexico who were undergoing cART treatment.

\section{Patients And Methods}

The present investigation was a cross-sectional, comparative, descriptive and analytical study. Participants were recruited from the Outpatient Centers for the Prevention and Care of AIDS and Sexually Transmitted Infections (CAPASITS) of Torreon, Coahuila, Mexico, and the Hospital Comprehensive Care Services (SAlH) of Gomez Palacio, Durango in Mexico. All patients were examined for CD4+ counting and viral load in blood, along with serum lipid profile, glucose and insulin resistance determination. This study was approved by the Bioethics Committee of the Faculty of Medicine of the Autonomous University of Coahuila, in Torreon, Mexico (ref C.B/08-10-17). This research also adhered to the criteria of the Declaration of Helsinki established for medical research involving human subjects.

\section{Participants}

The sample consisted of 186 HIV-positive patients over 18 years of age who were under cART treatment as shown in Table S1. Insufficient sample and/or incomplete medical history were considered as elimination criteria. All participants signed an informed consent letter. In addition, a questionnaire was applied to each individual to describe history of HIV infection, sociodemographic data, along with cardiovascular risk factors such as smoking, hypertension and diabetes, and verification of treatment adherence. The inclusion criteria were women and men, over 18 years with established diagnosis of HIV infection, antiretroviral treatment and letter of informed consent. The exclusion criteria were subject has any type of cancer or lymphoma and chemotherapy treatment; and elimination criteria the elimination criteria considered were insufficient or degraded samples and incomplete medical history.

\section{Anthropometric measures}

The body weight of participants was measured by an electronic balance (Beurer, Gmbh Soflinger, Str. 218 Germany), whereas height was measured using a stadiometer. The body mass index (BMI) was defined according to World Health Organization (WHO) criteria $\left(\mathrm{kg} / \mathrm{m}^{2}\right)$ : (i) low weight (<18.5 kg/m²), (ii) normal weight (18.5-24.9 kg/m²), (iii) overweight $\left(25-29.9 \mathrm{~kg} / \mathrm{m}^{2}\right)$ and obesity $\left(\geq 30 \mathrm{~kg} / \mathrm{m}^{2}\right)(29)$. The abdominal circumference was measured with a tape, considering as reference values for centripetal obesity a circumference in men>90 cm and in women>80 cm. The presence/absence of metabolic syndrome 
was evaluated based on the WHO criteria (triglycerides $\geq 150 \mathrm{mg} / \mathrm{dL}$, blood pressure $130 / 85 \mathrm{mmHg}$ and insulin resistance) (30). Blood pressure was measured using an electronic device (Equaline BW-323A, Taiwan) and normality was defined with values of 110-120 mmHg of systolic pressure and 60-80 $\mathrm{mmHg}$ of diastolic pressure.

\section{Biochemical measures}

Fasting peripheral blood samples $(4 \mathrm{~mL})$ were taken by venipuncture in a tube with EDTA and $(5 \mathrm{~mL})$ in another tube without anticoagulant. The lipid profile characterization was performed by conventional clinical laboratory methods. Biochemical parameters were measured by the Vitros ${ }^{\circledR} 250$ Chemistry System. The atherogenic index was defined as total cholesterol $(\mathrm{mg} / \mathrm{dL}) / \mathrm{high}$-density lipoprotein $(\mathrm{HDL})(\mathrm{mg} / \mathrm{dL})$. Insulin resistance with homeostatic model assessment (HOMA) index was defined as glucose $(\mathrm{mg} / \mathrm{dL}) *$ insulin $(\mathrm{mg} / \mathrm{dL}) / 405$.

\section{Cardiovascular Risk Assessment}

The cardiovascular risk of each participant was calculated using two logarithmic models: D:A:D (5-year risk) and Framingham (10-year risk). Both models estimate the risk of cardiovascular disease by combining information on age, sex, systolic blood pressure, total cholesterol, HDL, diabetes and smoking. While the equation of D:A:D includes the use of antiretroviral therapy $(31,32)$, Framingham's equation estimates the risk including antihypertensive therapy, but not antiretroviral therapy $(32,33)$. In addition, for the D:A:D model we used two versions: D:A:D reduced (including age, gender, systolic blood pressure, smoking, family history of CVD, diabetes, total cholesterol, high-density lipoprotein, CD4 cell count) and D:A:D full model (including age, gender, systolic blood pressure, smoking, family history of CVD, diabetes, total cholesterol, high-density lipoprotein, CD4 cell count, cumulative exposure to protease and reverse transcriptase nucleoside-inhibitors and current use of abacavir). Finally, the risk for participants according to D:A:D was considered as low (<1\%), moderate (1-5\%), high (5$10 \%)$, and very high ( $>10 \%)$; the risk according to Framingham was low ( $<10 \%)$, moderate $(10-20 \%)$, high $(21-30 \%)$ and very high (>30\%) $(31)$.

\section{Statistical analysis}

Data was analyzed using the statistical software package SPSS v21.0 (IBM Corp, Chicago IL, USA). Sociodemographic and clinical quantitative variables were analyzed using central tendency and dispersion measurements (i.e., means and standard deviations). In addition, Mann-Whitney U test was used to compare non-normally distributed quantitative variables. Odds ratios and multinomial logistic regression were used to measure association strength. Finally, $\mathrm{p}$-values $<0.05$ were considered as statistically significant.

\section{Results}

\section{Sociodemographic and clinical characteristics}

The sample consisted of 186 participants, 145 males (77.4\%), and 41 (22.6\%) females, with a mean age of 39.1 years (Table 1). In addition, $45.6 \%$ of the participants were homosexual, $44.4 \%$ heterosexual, and $10 \%$ bisexual. At the time of the study, all patients were receiving cART with a mean treatment of 7.18 $( \pm 6.15)$ years and $9.73( \pm 6.46)$ years with the infection. Seventy out of the 186 participants $(37.6 \%)$ were reported as smokers and 94 individuals $(50.5 \%)$ as former smokers. According to metabolic parameters, $51.3 \%$ of the total population sample had a history of hypertension, whereas $5.4 \%$ were individuals with T2D. The mean count of CD4+ at the beginning of the treatment was $520.17\left( \pm 438.62 \mathrm{cell} / \mathrm{mm}^{3}\right)$. Regarding cART treatment, $\sim 65 \%$ of the participants were under a treatment scheme of two nucleoside inhibitors plus a non-nucleoside reverse transcriptase inhibitor (Table S1).

\section{Physical examination and biological profile of the participants}

The mean of BMI was $25.44 \pm 5.3 \mathrm{~kg} / \mathrm{m}^{2}$. Approximately, $4.3 \%$ of the participants were classified as underweight, $49.5 \%$ with normal weight, $28.5 \%$ with overweight, and $17.7 \%$ with obesity. One hundred patients (53.8\%) had hypertriglyceridemia, 44 (23.7\%) hypercholesterolemia, 72 (38.7\%) presented HDL levels $<40 \mathrm{mg} / \mathrm{dL}, 69(37.7 \%)$ subjects had insulin resistance and $102(54.8 \%)$ met the criteria to be classified with metabolic syndrome. When the groups were compared according to sex, HDL levels were significantly higher in women (Table 1).

In the bivariate analysis, $\mathrm{HDL}$ showed an association with gender $(p=0.04)$ and $\mathrm{BMI}(p=0.02)$. Moreover, total cholesterol was associated with smoking $(p=0.048)$, whereas triglycerides and atherogenic index were associated with the presence of metabolic syndrome $(p<0.001)($ Table 2$)$.

\section{Cardiovascular Risk Assessment}

The average cardiovascular risk according to the Framingham algorithmic model was $2.63 \%( \pm 5.80)$. On the other hand, for the D:A:D algorithmic model (5 year prediction), the average risk in the reduced model was $2.3 \%( \pm 2.69)$ whereas for the full model, estimated risk was $3.11 \%( \pm 4.64)$, indicating a moderate risk (Table 3). In addition, when comparing the three algorithmic models, along with sex, smoking, diabetes and age, D:A:D full model showed to be more specific for the prediction of a cardiovascular event in a period of five to 10 years for people who lives with HIV (Table 3).

When comparing cardiovascular risk using the Framingham and D:A:D algorithmic models stratified by BMI (normal weight, overweight and obese) no statistically significant differences were found; however, it can be observed that the risk is high with the D:A:D full model in the normal weight group compared to overweight/obesity (Table 4).

Finally, Table 5 shows a multivariate analysis of risk factors in which only smoking remained significant $(p=0.002)$ after adjustment by age and sex for the Framingham model, whereas smoking and age were significant for D:A:D reduced model only ( $p=0.020$ and $p<0.001$, respectively). 
In individuals under cART attrition has become less common. Recent studies performed in high and low income countries have reported weight gain regardless of the type of CART used (34-39). Among the most common co-morbidities among people living with HIV are type 2 diabetes, hypertension, respiratory diseases and liver disease, among others. (40-43). Cardiovascular disease is a comorbidity of HIV infection which has also been linked to cART exposure in the HIV-seropositive population (44). It is known that comorbidity increases with HIV severity. The greater prevalence of comorbidities among people living with HIV/AIDS (PLWHA) may be attributed to antiretroviral toxicity (e.g. diabetes, vascular disease and liver disease) or caused by the HIV infection itself (e.g. vascular, pulmonary and renal diseases) $(43,45)$. The use of antiretroviral therapy has been associated with obesity. Non-nucleoside reverse transcriptase inhibitors (NNRTIs), protease inhibitors (PIs) and integrase inhibitors (IIs) are among the most commonly associated, as they are lipophilic and susceptible to diffusion in adipose tissue, which concentrates antiviral activity and is related to plasma antiviral concentrations. (46, 47).

Cardiovascular risk estimation, based on the Framingham score, was designed in the general population, but its use in people living with HIV is not well defined(28). Based on the prospective multicentre D:A:D study, which included 11 cohorts of HIV-positive patients treated in 212 clinics in the US, Europe, Argentina and Australia, algorithms were developed specifically for this population. The DAD score was first published in 2010, and took into account CD4+ cell count, abacavir use, and time of exposure to protease inhibitors and nucleoside reverse transcriptase inhibitors, in addition to classical cardiovascular risk factors. In order to simplify patient risk as well as take into account antiretroviral therapy, a change in the D: A: D score was established and published in 2016, assessing the same clinical outcomes over 5 years, but without using the classes and time of exposure to cART $(27,48)$.

In our study, we evaluated different metabolic alterations in HIV-seropositive Mexican subjects, which were under cART treatment. We observed that prevalence of dyslipidemias (hypercholesterolemia, hypertriglyceridemia, $\mathrm{HDL}<40 \mathrm{mg} / \mathrm{dL}$ ) was in $\sim 38.6 \%$ of the individuals. Also this prevalence was higher in a population of China, which was $75.4 \%$ (49). It is known that lipid abnormalities prevail in HIV-seropositive people with cART and may contribute to increased risk of cardiovascular disease (50).

Mexico has been characterized by having a high prevalence of obesity in the HIV-seronegative population, in which 75\% of population has been classified as overweight/obesity based on BMI criteria (51). In addition, the study conducted by Xiaonli et al., 2019 in China showed that the male population presented a higher prevalence of overweight compared to the female population. Based on the WHO criteria for general population, we found that 54.8\% of the participants in this study presented metabolic syndrome. In contrast, in a study conducted by Sear et al., 2019 the prevalence of metabolic syndrome was $34 \%$ in an HIV-seropositive population from Southern United States (52). This percentage was also higher than that from a population of Bologna, Italy, where the prevalence of metabolic syndrome was $20.9 \%(53)$. Globally, it is estimated that the metabolic syndrome in the HIV-seropositive population is $29.6 \%$ (according to the ATPIII criteria), which is similar to that of a population not infected with HIV (54). Approximately $46.2 \%$ of our studied population was in overweight/obesity status, although still lower that an HIV-seropositive population from Peru which presented 52.70\% (55). In a study in several populations from Latin America (Venezuela, Brazil, Colombia, Peru and Ecuador), in which PLWHA showed a high prevalence of metabolic syndrome, and $44 \%$ of the participants were under IP treatment (56). In the present study, we found a prevalence of $54.8 \%$ of the population with metabolic syndromes, with $65 \%$ of the participants receiving $2 \mathrm{NTRI}+1 \mathrm{NNTRI}$ in their treatment scheme.

In a study performed in a Ghanaian population in 2015, where the levels of transaminases in an HIV-positive population under treatment were compared by sex, values were found within normal parameters (57). However, in our study, when comparing the glutamic oxaloacetic transaminase (GOT)/glutamic-pyruvic transaminase (GTP) values by sex, a significant difference was found, in which males presented the highest levels. This could lead to the hypothesis that, because the male population has a higher BMI, GOT/GTP values could be different from normal parameters and could be involved in the development of nonalcoholic fatty liver disease (NAFLD)/non-alcoholic steatohepatitis (NASH). NALDF It is a liver disease that has been associated with obesity, diabetes and metabolic syndrome (58). Liver disease-related morbidity in people living with HIV remains high, even with advances in hepatitis treatment. NALDF has a prevalence of $50 \%$. Factors such as insulin resistance, mitochondrial dysfunction and dyslipidaemia appear to be major factors for the increase in NALDF and NASH in people living with HIV. HIV infection combined with antiretroviral therapy increases the risk of developing NALDF. The use of first generation nucleoside reverse transcriptase inhibitors and protease inhibitors is also associated with the development of NAFLD/NASH.(59).

In this study, HDL levels in the HIV-seropositive male population were lower compared to the female population. HDL low levels (<40 mg/dL) in men have been also reported in one HIV-seropositive Brazilian population (60) and one HIV-seropositive population from Medellin, Colombia (61). It has been also described that the activity of the cholesterol ester transfer protein (CETP), which transfers HDL-C cholesterol esters to proteins containing apolipoprotein B (62, 63), is high in HIV infection, thus, its activity is inversely correlated with serum HDL levels $(63,64)$. This may explain why these HDL-C low levels are present in HIV infected patients (63).

In this work, it was also observed that the relationship between lipid profile and risk variables (such as smoking) may influence the development of hypercholesterolemia, which may increase the risk of developing heart disease. A previous report in a Japanese population showed that this association (smoking and hypercholesterolemia) may influence the development of ischemic cardiovascular accident and coronary artery disease (65). Also, it is well known that the use of tobacco may increase cholesterol levels in individuals $(66,67)$ and becomes a risk factor for the development of myocardial infarction in the general population since it is also associated with an increase in the lipid profile (68).

The presence of metabolic syndrome observed in our HIV-seropositive population was considerably high (54.8\%). However, a study conducted in India showed higher percentages (91\%) for these two conditions in HIV-seropositive subjects (69). Metabolic syndrome is an independent predictive factor of cardiovascular disease (CVD) in HIV-infected individuals, however, there is also a strong association between the increasing number of metabolic syndrome components and the risk of CVD, emphasizing the importance of identification and management of all CVD factors in HIV-seropositive population under cART treatment (70). According to the literature, the presence of metabolic syndrome is positively correlated with atherogenic index, being known as a good predictor for the presence of a cardiovascular event. Thus, the atherogenic index may be an important factor that affects the risk of cardiovascular disease among people infected with HIV (71). 
Among the analyzed cardiovascular risk factors in the D:A:D models, one of the most significant associations was smoking. The prevalence of smoking in HIV-seropositive population is similar compared to the general population (72-74). The risk factors that were identified for the development of a cardiovascular disease through the D:A:D model are the male gender, as well as age (75).

Different factors such as hypercholesterolemia have been associated within the increased risk of cardiovascular disease (HR 1.21 Cl 1.16-1.27) (76). When performing the associations, hypercholesterolemia was found as a risk factor; however, when adjusting for age, no association was found for this variable. Another factor that has been increased in people living with HIV/AIDS in CART is triglyceride levels (hypertriglyceridemia) where high levels have been associated with cardiovascular risk (75).

In this study, when performing the associations, hypertriglyceridemia was identified as a risk factor; however, when adjusting for age it was not possible to establish as a possible cardiovascular risk factor. By analyzing the years under treatment ( $\geq 10$ years) of patients living with HIV, it was observed that this could be a risk factor in the study population when analyzed with D:A:D full model: however, When performing the multinomial analysis, it could not be established as a risk factor. Kumar et al., 2016, in an HIV-positive HIV population, found that influence the increase in cardiovascular risk and the presence of lipodystrophy; therefore, patients with HIV in CART are advised to undergo an early detection of cardiovascular risk and take appropriate measures to prevent progression to cardiac risk (77). In HIV-positive individuals with preserved immunity, immediate antiretroviral therapy has been shown to increase total cholesterol and low-density lipoproteins, as well as continuous increases in high-density lipoprotein cholesterol.. These opposite effects suggest that, in the short term, the effect of early CART on the risk factors of traditional cardiovascular disease may be clinically insignificant (78). In this study, it was observed that the use of 2INTR + 2INNTR was associated with increased cardiovascular risk with the D:A:D full model; however, when adjusting for age, this association was not significant,. With the use of INNTR + INTR or PI + INTR, the cardiovascular risk was increased in people living with HIV with cART (OR 1.11 IC 1.051.17) (79). Demessine et al. 2019 showed that the use of INNTR + 2 INTR increases cardiovascular risk $(0 R, 4.12 ; 95 \%$ Cl, 3.34-5.10; P <.0001) (80).

Finally, regarding the two algorithms used in this work, the Framingham algorithmic model showed a low cardiovascular risk (<10\%) compared to the D:A:D model that was specific for people living with HIV/AIDS with CART, which showed a moderate risk (>1\%). Cardiovascular risk assessment in people living with HIV using different algorithmic models such as Framingham, ACC/AHA, PE and D:A:D is increased or shows a low to moderate risk (81, 82). According to the literature, comparison of various algorithmic models that estimate cardiovascular risk such as Framingham, PROCAM, D:A:D in people living with HIV, it is mentioned that only FRS has a more accurate prediction of a cardiac event, while PCE and D:A:D underestimate the risk of a cardiovascular event (83). The use of these tools to identify patients with a cardiovascular risk profile seems to be a simple way to monitor long-term CVD risks in the population of HIVinfected patients (84) and to define whose patients will need further assessment.

\section{Conclusion}

In this study with PLWH on ART, it was found that the factors that increase the risk and onset of cardiovascular disease at an early age are hypercholesterolemia, hypertriglyceridemia, metabolic syndrome, insulin resistance, smoking and age. In addition, the algorithmic models D: A: D and Framingham algorithmic models for estimating cardiovascular risk show a low to moderate risk; however, because the population is young, the results of cardiovascular risk should be taken with caution; in addition, exposure to ART, as well as years of infection and years under treatment, should be taken into account..

\section{Declarations}

\section{Competing Interests}

The authors have declared that no competing interests exist.

Funding: The research did not receive financial support from any institution

Conflicts of interest/Competing interests: The authors have declared that no competing interests exist.

Availability of data and material (data transparency): All data are contained in the manuscript

Code availability (software application or custom code): Not applicable

Ethics approval (include appropriate approvals or waivers): Attached document

Authors' contributions (optional: please review the submission guidelines from the journal whether statements are mandatory) Not applicable

Consent to participate (include appropriate statements): Not applicable

Consent for publication (include appropriate statements) Not applicable

\section{References}

1. McManus H, O'Connor CC, Boyd M, Broom J, Russell D, Watson K, et al. Long-term survival in HIV positive patients with up to 15 Years of antiretroviral therapy. PLoS One. 2012;7(11):e48839.

2. Friis-Møller N, Ryom L, Smith C, Weber R, Reiss P, Dabis F, et al. An updated prediction model of the global risk of cardiovascular disease in HIV-positive persons: The Data-collection on Adverse Effects of Anti-HIV Drugs (D: A: D) study. European journal of preventive cardiology. 2016;23(2):214-23.

Page 5/11 
3. Deeks SG, Phillips AN. HIV infection, antiretroviral treatment, ageing, and non-AIDS related morbidity. Bmj. 2009;338:a3172.

4. Effros RB, Fletcher CV, Gebo K, Halter JB, Hazzard WR, Horne FM, et al. Workshop on HIV infection and aging: what is known and future research directions. Clinical infectious diseases: an official publication of the Infectious Diseases Society of America. 2008;47(4):542.

5. Marzolini C, Elzi L, Gibbons S, Weber R, Fux C, Furrer H, et al. Prevalence of comedications and effect of potential drug-drug interactions in the Swiss HIV Cohort Study. Antiviral therapy. 2010;15(3):413.

6. Hasse B, Ledergerber B, Furrer H, Battegay M, Hirschel B, Cavassini M, et al. Morbidity and Aging in HIV-Infected Persons: The Swiss HIV Cohort Study. Clinical Infectious Diseases. 2011;53(11):1130-9.

7. Triant VA, Lee H, Hadigan C, Grinspoon SK. Increased acute myocardial infarction rates and cardiovascular risk factors among patients with human immunodeficiency virus disease. The Journal of Clinical Endocrinology \& Metabolism. 2007;92(7):2506-12.

8. Kazooba P, Kasamba I, Mayanja BN, Lutaakome J, Namakoola I, Salome T, et al. Cardiometabolic risk among HIV-POSITIVE Ugandan adults: prevalence, predictors and effect of long-term antiretroviral therapy. Pan African Medical Journal. 2017;27(1).

9. Bergersen BM. Cardiovascular risk in patients with HIV Infection: impact of antiretroviral therapy. Drugs. 2006;66(15):1971-87.

10. D'Agostino RB, Sr. Cardiovascular risk estimation in 2012: lessons learned and applicability to the HIV population. The Journal of infectious diseases. 2012;205 Suppl 3:S362-7.

11. Friis-Moller N, Worm SW. Can the risk of cardiovascular disease in HIV-infected patients be estimated from conventional risk prediction tools? Clinical infectious diseases : an official publication of the Infectious Diseases Society of America. 2007;45(8):1082-4.

12. Pirš M, Jug B, Eržen B, Šabović M, Karner P, Poljak M, et al. Cardiovascular risk assessment in HIV-infected male patients: a comparison of Framingham, SCORE, PROCAM and DAD risk equations. Acta dermatovenerologica Alpina, Pannonica, et Adriatica. 2014;23(3):43-7.

13. Moreira Guimaraes MM, Bartolomeu Greco D, Ingles Garces AH, de Oliveira AR, Jr., Bastos Foscolo R, de Campos Machado LJ. Coronary heart disease risk assessment in HIV-infected patients: a comparison of Framingham, PROCAM and SCORE risk assessment functions. Int J Clin Pract. 2010;64(6):739-45.

14. Knobel H, Jerico C, Montero M, Sorli ML, Velat M, Guelar A, et al. Global cardiovascular risk in patients with HIV infection: concordance and differences in estimates according to three risk equations (Framingham, SCORE, and PROCAM). AIDS patient care and STDs. 2007;21(7):452-7.

15. Edwards-Jackson N, Kerr S, Tieu H, Ananworanich J, Hammer S, Ruxrungtham K, et al. Cardiovascular risk assessment in persons with HIV infection in the developing world: comparing three risk equations in a cohort of HIV-infected Thais. HIV medicine. 2011;12(8):510-5.

16. Kaplan RC, Kingsley LA, Sharrett AR, Li X, Lazar J, Tien PC, et al. Ten-year predicted coronary heart disease risk in HIV-infected men and women. Clinical infectious diseases : an official publication of the Infectious Diseases Society of America. 2007;45(8):1074-81.

17. Friis-Moller N, Ryom L, Smith C, Weber R, Reiss P, Dabis F, et al. An updated prediction model of the global risk of cardiovascular disease in HIV-positive persons: The Data-collection on Adverse Effects of Anti-HIV Drugs (D:A:D) study. Eur J Prev Cardiol. 2016;23(2):214-23.

18. Mary-Krause M, Cotte L, Simon A, Partisani M, Costagliola D. Increased risk of myocardial infarction with duration of protease inhibitor therapy in HIVinfected men. AIDS (London, England). 2003;17(17):2479-86.

19. Holmberg SD, Moorman AC, Williamson JM, Tong TC, Ward DJ, Wood KC, et al. Protease inhibitors and cardiovascular outcomes in patients with HIV-1. Lancet (London, England). 2002;360(9347):1747-8.

20. Iloeje UH, Yuan Y, L'Italien G, Mauskopf J, Holmberg SD, Moorman AC, et al. Protease inhibitor exposure and increased risk of cardiovascular disease in HIV-infected patients. HIV medicine. 2005;6(1):37-44.

21. Currier JS, Taylor A, Boyd F, Dezii CM, Kawabata H, Burtcel B, et al. Coronary heart disease in HIV-infected individuals. Journal of acquired immune deficiency syndromes (1999). 2003;33(4):506-12.

22. Durand M, Sheehy O, Baril J-G, Lelorier J, Tremblay CL. Association between HIV infection, antiretroviral therapy, and risk of acute myocardial infarction: a cohort and nested case-control study using Quebec's public health insurance database. JAIDS Journal of Acquired Immune Deficiency Syndromes. 2011;57(3):245-53.

23. Klein D, Hurley LB, Quesenberry JC, Sidney S. Do protease inhibitors increase the risk for coronary heart disease in patients with HIV-1 infection? Journal of acquired immune deficiency syndromes (1999). 2002;30(5):471-7.

24. Lang S, Mary-Krause M, Cotte L, Gilquin J, Partisani M, Simon A, et al. Increased risk of myocardial infarction in HIV-infected patients in France, relative to the general population. AIDS (London, England). 2010;24(8):1228-30.

25. Obel N, Thomsen HF, Kronborg G, Larsen CS, Hildebrandt PR, Sørensen HT, et al. Ischemic heart disease in HIV-infected and HIV-uninfected individuals: a population-based cohort study. Clinical Infectious Diseases. 2007;44(12):1625-31.

26. Triant VA. Cardiovascular disease and HIV infection. Current HIV/AIDS Reports. 2013;10(3):199-206.

27. Friis-Møller N, Thiébaut R, Reiss P, Weber R, Monforte AD, De Wit S, et al. Predicting the risk of cardiovascular disease in HIV-infected patients: the data collection on adverse effects of anti-HIV drugs study. Eur J Cardiovasc Prev Rehabil. 2010;17(5):491-501.

28. Edwards-Jackson N, Kerr S, Tieu H, Ananworanich J, Hammer S, Ruxrungtham K, et al. Cardiovascular risk assessment in persons with HIV in the developing world: comparing three risk equations in a cohort of HIV-infected Thais. Journal of the International AIDS Society. 2010;13(S4):040.

29. Moreno GM. Definición y clasificación de la obesidad. Revista Médica Clínica Las Condes. 2012;23(2):124-8.

30. Lizarzaburu Robles JC, editor Síndrome metabólico: concepto y aplicación práctica. Anales de la Facultad de Medicina; 2013: UNMSM. Facultad de Medicina.

31. Friis-Moller N, Thiebaut R, Reiss P, Weber R, Monforte AD, De Wit S, et al. Predicting the risk of cardiovascular disease in HIV-infected patients: the data collection on adverse effects of anti-HIV drugs study. European journal of cardiovascular prevention and rehabilitation : official journal of the European 
Society of Cardiology, Working Groups on Epidemiology \& Prevention and Cardiac Rehabilitation and Exercise Physiology. 2010;17(5):491-501.

32. Noumegni SR, Ama VJM, Assah FK, Bigna JJ, Nansseu JR, Kameni JAM, et al. Assessment of the agreement between the Framingham and DAD risk equations for estimating cardiovascular risk in adult Africans living with HIV infection: a cross-sectional study. Tropical diseases, travel medicine and vaccines. 2017;3:12.

33. Anderson KM, Odell PM, Wilson PW, Kannel WB. Cardiovascular disease risk profiles. American heart journal. 1991;121(1 Pt 2):293-8.

34. Ezechi L, Musa Z, Otobo V, Idigbe I, Ezechi O. Trends and risk factors for obesity among HIV positive Nigerians on antiretroviral therapy. Ceylon Medical Journal. 2016;61(2).

35. Guehi C, Badjé A, Gabillard D, Ouattara E, Koulé SO, Moh R, et al. High prevalence of being Overweight and Obese HIV-infected persons, before and after 24 months on early ART in the ANRS 12136 Temprano Trial. AIDS research and therapy. 2016;13(1):12.

36. Koethe JR, Jenkins CA, Lau B, Shepherd BE, Justice AC, Tate JP, et al. Rising obesity prevalence and weight gain among adults starting antiretroviral therapy in the United States and Canada. AIDS research and human retroviruses. 2016;32(1):50-8.

37. Amorosa V, Synnestvedt M, Gross R, Friedman H, MacGregor RR, Gudonis D, et al. A tale of 2 epidemics: the intersection between obesity and HIV infection in Philadelphia. JAIDS Journal of Acquired Immune Deficiency Syndromes. 2005;39(5):557-61.

38. Gomes A, Reyes EV, Garduno LS, Rojas R, Mesejo GM, Del Rosario E, et al. Incidence of diabetes mellitus and obesity and the overlap of comorbidities in HIV+ hispanics initiating antiretroviral therapy. PloS one. 2016;11(8):e0160797.

39. Bakal DR, Coelho LE, Luz PM, Clark JL, De Boni RB, Cardoso SW, et al. Obesity following ART initiation is common and influenced by both traditional and HIV-/ART-specific risk factors. Journal of Antimicrobial Chemotherapy. 2018;73(8):2177-85.

40. Turner J, Bansi L, Gilson R, Gazzard B, Walsh J, Pillay D, et al. The prevalence of hepatitis C virus (HCV) infection in HIV-positive individuals in the UKtrends in HCV testing and the impact of HCV on HIV treatment outcomes. Journal of viral hepatitis. 2010;17(8):569-77.

41. Sudano I, Spieker LE, Noll G, Corti R, Weber R, Lüscher TF. Cardiovascular disease in HIV infection. American heart journal. 2006;151(6):1147-55.

42. Crothers K, Butt AA, Gibert CL, Rodriguez-Barradas MC, Crystal S, Justice AC. Increased COPD among HIV-positive compared to HIV-negative veterans. Chest. 2006;130(5):1326-33.

43. Lorenc A, Ananthavarathan P, Lorigan J, Banarsee R, Jowata M, Brook G. The prevalence of comorbidities among people living with HIV in Brent: a diverse London Borough. London journal of primary care. 2014;6(4):84-90.

44. Nsagha DS, Assob JCN, Njunda AL, Tanue EA, Kibu OD, Ayima CW, et al. Risk factors of cardiovascular diseases in HIV/AIDS patients on HAART. The open AIDS journal. 2015;9:51.

45. Goulet JL, Fultz SL, Rimland D, Butt A, Gibert C, Rodriguez-Barradas M, et al. Do patterns of comorbidity vary by HIV status, age, and HIV severity? Clinical Infectious Diseases. 2007;45(12):1593-601.

46. Services. DoHaH. Panel on Antiretroviral Guidelines for Adults and Adolescents. Guidelines for the use of antiretroviral agents in HIV-1-infected adults and adolescents. AIDSinfo. Available at:.

47. Madelain V, Le MP, Champenois K, Charpentier C, Landman R, Joly V, et al. Impact of obesity on antiretroviral pharmacokinetics and immuno-virological response in HIV-infected patients: a case-control study. Journal of Antimicrobial Chemotherapy. 2017;72(4):1137-46.

48. Silva AG, Paulo RV, Silva-Vergara ML. Subclinical Carotid Atherosclerosis and Reduced DAD Score for Cardiovascular Risk Stratification in HIV-Positive Patients. Arquivos Brasileiros de Cardiologia. 2020;114(1):68-75.

49. Shen Y, Wang J, Wang Z, Qi T, Song W, Tang Y, et al. Prevalence of Dyslipidemia Among Antiretroviral-Naive HIV-Infected Individuals in China. Medicine. 2015;94(48):e2201-e.

50. Waters DD, Hsue PY. Lipid abnormalities in persons living with HIV infection. Canadian Journal of Cardiology. 2018.

51. Romero-Martínez M, Shamah-Levy T, Vielma-Orozco E, Heredia-Hernández O, Mojica-Cuevas J, Cuevas-Nasu L, et al. Encuesta Nacional de Salud y Nutrición (Ensanut 2018): metodología y perspectivas. salud pública de méxico. 2019;61(6, nov-dic):917-23.

52. Sears S, Buendia JR, Odem S, Qobadi M, Wortley P, Mgbere O, et al. Metabolic Syndrome Among People Living with HIV Receiving Medical Care in Southern United States: Prevalence and Risk Factors. AIDS and Behavior. 2019:1-10.

53. Calza L, Colangeli V, Magistrelli E, Rossi N, Rosselli Del Turco E, Bussini L, et al. Prevalence of metabolic syndrome in HIV-infected patients naive to antiretroviral therapy or receiving a first-line treatment. HIV clinical trials. 2017;18(3):110-7.

54. Nguyen KA, Peer N, Mills EJ, Kengne AP. A meta-analysis of the metabolic syndrome prevalence in the global HIV-infected population. PloS one. 2016;11(3):e0150970.

55. Hidalgo JA, Florez A, Agurto C, Pinedo Y, Ayarza R, Rodriguez L, et al. Metabolic and Cardiovascular Comorbidities Among Clinically Stable HIV Patients on Long-Term ARV Therapy in Five Ambulatory Clinics in Lima-Callao, Peru. The open AIDS journal. 2018;12:126-35.

56. Alvarez C, Salazar R, Galindez J, Rangel F, Castaaeda ML, Lopardo G, et al. Metabolic syndrome in HIV-infected patients receiving antiretroviral therapy in Latin America. The Brazilian journal of infectious diseases : an official publication of the Brazilian Society of Infectious Diseases. 2010;14(3):256-63.

57. Osakunor DNM, Obirikorang C, Fianu V, Asare I, Dakorah M. Hepatic Enzyme Alterations in HIV Patients on Antiretroviral Therapy: A Case-Control Study in a Hospital Setting in Ghana. PLOS ONE. 2015;10(8):e0134449.

58. Kleiner DE, Makhlouf HR. Histology of nonalcoholic fatty liver disease and nonalcoholic steatohepatitis in adults and children. Clinics in liver disease. 2016;20(2):293-312.

59. van Welzen BJ, Mudrikova T, El Idrissi A, Hoepelman AIM, Arends JE. A Review of Non-Alcoholic Fatty Liver Disease in HIV-Infected Patients: The Next Big Thing? Infect Dis Ther. 2019;8(1):33-50.

Page $7 / 11$ 
60. Daminelli EN, Spada C, Treitinger A, Oliveira TV, Latrilha MdC, Maranhão RC. Alterations in lipid transfer to high-density lipoprotein (HDL) and activity of paraoxonase-1 in HIV+ patients. Revista do Instituto de Medicina Tropical de São Paulo. 2008;50(4):223-7.

61. Marin-Palma D, Castro GA, Cardona JA, Urcuqui-Inchima S, Hernandez JC. Lower High-Density Lipoproteins Levels during HIV-1 Infection are Associated with Increased Inflammatory Markers and Disease Progression. Frontiers in Immunology. 2018;9:1350.

62. Lewis GF, Rader DJ. New insights into the regulation of HDL metabolism and reverse cholesterol transport. Circulation research. 2005;96(12):1221-32.

63. Feeney ER, Mallon PW. HIV and HAART-Associated Dyslipidemia. The open cardiovascular medicine journal. 2011;5:49-63.

64. Rose H, Hoy J, Woolley I, Tchoua U, Bukrinsky M, Dart A, et al. HIV infection and high density lipoprotein metabolism. Atherosclerosis. 2008;199(1):79-86.

65. Hata J, Doi Y, Ninomiya T, Fukuhara M, Ikeda F, Mukai N, et al. Combined Effects of Smoking and Hypercholesterolemia on the Risk of Stroke and Coronary Heart Disease in Japanese: The Hisayama Study. Cerebrovascular Diseases. 2011;31(5):477-84.

66. Singh D. Effect of cigarette smoking on serum lipid profile in male population of Udaipur (Rajasthan). Int J Clin Biochem Res. 2016;3:368-70.

67. Tucker LA. Use of smokeless tobacco, cigarette smoking, and hypercholesterolemia. American Journal of Public Health. 1989;79(8):1048-50.

68. Attard R, Dingli P, Doggen CJ, Cassar K, Farrugia R, Wettinger SB. The impact of passive and active smoking on inflammation, lipid profile and the risk of myocardial infarction. Open heart. 2017;4(2):e000620.

69. Theengh DP, Yadav P, Jain AK, Nandy P. Assessment of metabolic syndrome in HIV-infected individuals. Indian journal of sexually transmitted diseases and AIDS. 2017;38(2):152-6.

70. Worm SW, Sabin CA, Reiss P, El-Sadr W, Monforte A, Pradier C, et al. Presence of the metabolic syndrome is not a better predictor of cardiovascular disease than the sum of its components in HIV-infected individuals: data collection on adverse events of anti-HIV drugs (D:A:D) study. Diabetes care. 2009;32(3):474-80.

71. Noumegni SR, Nansseu JR, Bigna JJ, Ama Moor VJ, Kembe Assah F, Dehayem MY, et al. Atherogenic index of plasma and 10-year risk of cardiovascular disease in adult Africans living with HIV infection: A cross-sectional study from Yaoundé, Cameroon. JRSM cardiovascular disease. 2017;6:2048004017740478.

72. Glass T, Ungsedhapand C, Wolbers M, Weber R, Vernazza P, Rickenbach M, et al. Prevalence of risk factors for cardiovascular disease in HIV-infected patients over time: the Swiss HIV Cohort Study. HIV medicine. 2006;7(6):404-10.

73. Nuesch R, Wang Q, Elzi L, Bernasconi E, Weber R, Cavassini M, et al. Risk of cardiovascular events and blood pressure control in hypertensive HIV-infected patients: Swiss HIV Cohort Study (SHCS). Journal of acquired immune deficiency syndromes (1999). 2013;62(4):396-404.

74. Hemkens LG, Bucher HC. HIV infection and cardiovascular disease. European Heart Journal. 2014;35(21):1373-81.

75. Friis-Møller N, Weber R, Reiss P, Thiébaut R, Kirk O, Monforte AdA, et al. Cardiovascular disease risk factors in HIV patients-association with antiretroviral therapy. Results from the DAD study. AIDS (London, England). 2003;17(8):1179-93.

76. Friis-Møller N, Thiebaut R, Reiss P, Weber R, D'Arminio Monforte A, De Wit S, et al. Predicting the risk of cardiovascular disease in HIV-infected patients: the data collection on adverse effects of anti-HIV drugs study. European journal of cardiovascular prevention \& rehabilitation. 2010;17(5):491-501.

77. Kumar D, Bohra GK, Agarwal M, Khichar S, Choudhary S, Midha N. Prediction of Cardiovascular Disease Risk Using Framingham and Data on Adverse Effect of Antiretroviral Drugs Risk Equation in Relation to Lipodystrophy in HIV Patients on Highly Active Antiretroviral Therapy. Journal of global infectious diseases. 2018;10(4):182-7.

78. Baker JV, Sharma S, Achhra AC, Bernardino JI, Bogner JR, Duprez D, et al. Changes in Cardiovascular Disease Risk Factors With Immediate Versus Deferred Antiretroviral Therapy Initiation Among HIV-Positive Participants in the START (Strategic Timing of Antiretroviral Treatment) Trial. Journal of the American Heart Association. 2017;6(5):e004987.

79. Islam F, Wu J, Jansson J, Wilson D. Relative risk of cardiovascular disease among people living with HIV: a systematic review and meta-analysis. HIV medicine. 2012;13(8):453-68.

80. Demessine L, Peyro-Saint-Paul L, Gardner EM, Ghosn J, Parienti J-J, editors. Risk and Cost Associated With Drug-Drug Interactions Among Aging HIV Patients Receiving Combined Antiretroviral Therapy in France. Open Forum Infectious Diseases; 2019: Oxford University Press US.

81. Raggi P, De Francesco D, Manicardi M, Zona S, Bellasi A, Stentarelli C, et al. Prediction of hard cardiovascular events in HIV patients. Journal of Antimicrobial Chemotherapy. 2016;71(12):3515-8.

82. Neto P, da Silva LF, Dias FR, Bressan FF, Santos CRO. Comparison of the ACC/AHA and Framingham algorithms to assess cardiovascular risk in HIVinfected patients. Brazilian Journal of Infectious Diseases. 2017;21(6):577-80.

83. Thompson-Paul AM, Lichtenstein KA, Armon C, Palella Jr FJ, Skarbinski J, Chmiel JS, et al. Cardiovascular disease risk prediction in the HIV outpatient study. Clinical Infectious Diseases. 2016;63(11):1508-16.

84. de Gaetano Donati K, Cauda R, lacoviello L. HIV Infection, Antiretroviral Therapy and Cardiovascular Risk. Mediterr J Hematol Infect Dis. 2010;2(3):e2010034.

\section{Tables}

Table 1. - Anthropometric, biochemical and clinical variables of individuals classified by gender. 


\begin{tabular}{|c|c|c|c|c|}
\hline Variable & All patients $(n=186)$ & Male $(n=145)$ & Female $(n=41)$ & $p$-value \\
\hline & Mean ( \pm s.d.) & Mean ( \pm s.d.) & Mean ( \pm s.d.) & \\
\hline Age & $39.14( \pm 10.89)$ & $38.92( \pm 0.914)$ & $39.93( \pm 1.671)$ & 0.608 \\
\hline Weight & $71.97( \pm 14.44)$ & $72.91( \pm 13.9)$ & $68.67( \pm 15.95)$ & 0.100 \\
\hline Height & $1.67( \pm 0.89)$ & $1.71( \pm 0.065)$ & $1.56( \pm 0.064)$ & $<0.0001$ \\
\hline BMI $\left(\mathrm{kg} / \mathrm{m}^{2}\right)$ & $25.44( \pm 5.3)$ & $24.88( \pm 4.43)$ & $28.04( \pm 5.96)$ & 0.027 \\
\hline Waist circumference $(\mathrm{cm})$ & $79.74( \pm 31.89)$ & $89.69( \pm 12.65)$ & $93.03( \pm 15.97)$ & 0.297 \\
\hline Blood pressure (mmHg) & $112 / 73( \pm 9.96)$ & $111 / 75( \pm 1.05)$ & $110 / 70( \pm 2.16)$ & 0.499 \\
\hline Glucose (mg/dL) & $91.38( \pm 30.57)$ & $90.82( \pm 29.62)$ & $93.37( \pm 33.85)$ & 0.578 \\
\hline Insulin (U-100) & $10.88( \pm 7.42)$ & $10.62( \pm 7.56)$ & $11.84( \pm 6.94)$ & 0.176 \\
\hline Insulin resistance & $2.64( \pm 2.32)$ & $2.57( \pm 2.39)$ & $2.86( \pm 2.05)$ & 0.158 \\
\hline Cholesterol (mmg/dL) & $174.8( \pm 38.44)$ & $173.6( \pm 39.22)$ & $178.9( \pm 35.72)$ & 0.421 \\
\hline Triglycerides (mmg/dL) & $225.5( \pm 202.11)$ & $225.5( \pm 211.3)$ & $192.9( \pm 165.5)$ & 0.367 \\
\hline $\mathrm{HDL}(\mathrm{mmg} / \mathrm{dL})$ & $46.23( \pm 13.44)$ & $44.88( \pm 12.67)$ & $51.00( \pm 15.08)$ & 0.012 \\
\hline LDL (mmg/dL) & $90.79( \pm 31.1)$ & $90.21( \pm 32.91)$ & $92.87( \pm 23.85)$ & 0.470 \\
\hline VLDL (mmg/dL) & $37.78( \pm 22.48)$ & $38.57( \pm 22.82)$ & $34.99( \pm 21.30)$ & 0.402 \\
\hline GOT (U/L) & $42.22( \pm 49.68)$ & $43.22( \pm 49.64)$ & $38.71( \pm 50.28)$ & 0.0002 \\
\hline GTP (U/L) & $50.74( \pm 61.55)$ & $54.17( \pm 68.06)$ & $34.63( \pm 25.56)$ & 0.02 \\
\hline Viral load (copies) & $11118.22( \pm 63217.11)$ & $10529( \pm 6257)$ & $13121( \pm 6710)$ & 0.996 \\
\hline $\mathrm{CD} 4+\mathrm{cel} / \mathrm{mm}^{3}$ & $447.84( \pm 276.78)$ & $437.0( \pm 278.8)$ & $486.3( \pm 270.4)$ & 0.238 \\
\hline
\end{tabular}

BMI: body mass index; HDL: high-density lipoprotein; LDL: low-density lipoprotein; VLDL: very low-density lipoprotein; GOT: glutamic oxaloacetic transaminase; GPT: glutamic-pyruvic transaminase; s.d.: standard deviation; p-values $<0.05$ after t-test comparison are shown in bold.

Table 2. - Association of lipid profile and risk factors in people with HIV/AIDS undergoing cART.

\begin{tabular}{|c|c|c|c|c|c|c|c|c|c|c|}
\hline & & & & & OR (IC 95\%) & & & & & \\
\hline Variable & & p- & & $\begin{array}{l}p- \\
\text { value }\end{array}$ & & $\begin{array}{l}p- \\
\text { value }\end{array}$ & & $\begin{array}{l}p- \\
\text { value }\end{array}$ & $\begin{array}{l}\text { Atherogenic } \\
\text { Index }\end{array}$ & $\begin{array}{l}p- \\
\text { value }\end{array}$ \\
\hline & $(>200$ & & $(<40$ & & $(>130$ & & $(>150 \mathrm{mg} / \mathrm{dL})$ & & & \\
\hline & 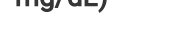 & & IIIy/ut) & & IIIy/ 나) & & OR (IC 95\%) & & $(-4.0)$ & \\
\hline & OR (IC 95\%) & & OR (IC 95\%) & & OR (IC 95\%) & & & & OR (IC 95\%) & \\
\hline & $\begin{array}{l}1.05(0.86- \\
1.27)\end{array}$ & 0.588 & $\begin{array}{l}1.27(0.94- \\
1.72)\end{array}$ & 0.04 & $\begin{array}{l}0.85(0.71- \\
1.02)\end{array}$ & 0.201 & $\begin{array}{l}0.91(0.78- \\
1.07)\end{array}$ & 0.280 & $\begin{array}{l}0.87(0.75- \\
1.02)\end{array}$ & 0.162 \\
\hline Female & $\begin{array}{l}0.84(0.46- \\
1.54)\end{array}$ & & $\begin{array}{l}0.52(0.29- \\
0.94)\end{array}$ & & $\begin{array}{l}2.21(0.58- \\
8.46)\end{array}$ & & $\begin{array}{l}1.34(0.78- \\
2.31)\end{array}$ & & $\begin{array}{l}1.78(0.75- \\
4.23)\end{array}$ & \\
\hline Age (>30 years) & $\begin{array}{l}0.96(0.47- \\
1.94)\end{array}$ & 0.901 & $\begin{array}{l}1.25(0.57- \\
2.78)\end{array}$ & 0.579 & $\begin{array}{l}0.19(0.13- \\
1.38)\end{array}$ & 0.055 & $\begin{array}{l}0.80(0.556- \\
1.147)\end{array}$ & 0.192 & $\begin{array}{l}1.26(1.12- \\
1.41)\end{array}$ & 0.051 \\
\hline Smoking & $\begin{array}{l}1.18(1.01- \\
1.37)^{-}\end{array}$ & 0.048 & $\begin{array}{l}1.08(0.97- \\
1.22)\end{array}$ & 0.174 & $\begin{array}{l}0.98(0.40- \\
2.34)\end{array}$ & 0.940 & $\begin{array}{l}1.15(0.833- \\
1.503)\end{array}$ & 0.307 & $\begin{array}{l}1.01(0.58- \\
1.83)\end{array}$ & 0.977 \\
\hline $\mathrm{BMI}\left(\geq 25.00 \mathrm{~kg} / \mathrm{m}^{2}\right)$ & $\begin{array}{l}1.74(0.83- \\
3.45)\end{array}$ & 0.107 & $\begin{array}{l}0.35(0.14- \\
0.88)\end{array}$ & 0.02 & $\begin{array}{l}2.15(0.80- \\
5.75)\end{array}$ & 0.118 & $\begin{array}{l}2.60(1.43- \\
4.73)\end{array}$ & 0.001 & $\begin{array}{l}1.48(0.72- \\
3.09)\end{array}$ & 0.287 \\
\hline Metabolic syndrome & $\begin{array}{l}1.11(0.56- \\
2.20)\end{array}$ & 0.763 & $\begin{array}{l}0.61(0.27- \\
1.39)\end{array}$ & 0.24 & $\begin{array}{l}0.44(0.17- \\
1.18)\end{array}$ & 0.096 & $\begin{array}{l}6.56(3.450- \\
12.45)\end{array}$ & $<0.001$ & $\begin{array}{l}5.64(2.23- \\
14.40)\end{array}$ & $<0.001$ \\
\hline $\begin{array}{l}\text { Blood pressure (>140 } \\
\mathrm{mmHg} \text { ) }\end{array}$ & $\begin{array}{l}0.24(0.18- \\
0.39)\end{array}$ & 0.074 & $\begin{array}{l}0.86(0.81- \\
0.96)\end{array}$ & 0.869 & $\begin{array}{l}0.90(0.85-0- \\
95)\end{array}$ & 0.736 & $\begin{array}{l}0.54(0.456- \\
0.618)\end{array}$ & 0.354 & $\begin{array}{l}0.79(0.73- \\
0.87)\end{array}$ & 0.606 \\
\hline $\mathrm{CD} 4+(<350 \mathrm{cel} / \mathrm{mm} 3)$ & $\begin{array}{l}0.80(0.45- \\
1.33)\end{array}$ & 0.359 & $\begin{array}{l}1.09(0.54- \\
2.20)\end{array}$ & 0.808 & $\begin{array}{l}0.80(0.33- \\
1.92)\end{array}$ & 0.610 & $\begin{array}{l}1.07(0.81- \\
1.40)\end{array}$ & 0.634 & $\begin{array}{l}0.97(0.54- \\
1.76)\end{array}$ & 0.931 \\
\hline Viral load (>50 copies) & $\begin{array}{l}0.63(0.23- \\
1.67)\end{array}$ & 0.344 & $\begin{array}{l}0.91(0.37- \\
2.26)\end{array}$ & 0.840 & $\begin{array}{l}0.46(0.10- \\
2.09)\end{array}$ & 0.304 & $\begin{array}{l}0.87(0.65- \\
1.15)\end{array}$ & 0.344 & $\begin{array}{l}0.66(0.34- \\
1.29)\end{array}$ & 0.240 \\
\hline cART & $\begin{array}{l}0.87(0.42- \\
1.81)\end{array}$ & 0.708 & $\begin{array}{l}0.80(0.42- \\
1.53)\end{array}$ & 0.503 & $\begin{array}{l}1.21(0.43- \\
3.31)\end{array}$ & 0.708 & $\begin{array}{l}1.36(0.72- \\
2.57)\end{array}$ & 0.344 & $\begin{array}{l}1.40(0.65- \\
3.03)\end{array}$ & 0.319 \\
\hline
\end{tabular}


BMI: body mass index; cART: highly active antiretroviral therapy; $\mathrm{p}$-values $<0.05$ after bivariate analysis are shown in bold.

Table 3. - Cardiovascular risk assessment according to the Framingham and D:A:D algorithmic models.

\begin{tabular}{|c|c|c|c|c|c|c|c|c|c|c|c|c|c|}
\hline & \multicolumn{4}{|c|}{ Low risk (\%) } & \multicolumn{4}{|c|}{ Moderate risk (\%) } & \multicolumn{4}{|c|}{ High risk (\%) } & \multirow{2}{*}{$\begin{array}{l}\text { Very-higl } \\
\text { Framing } \\
\text { ham }\end{array}$} \\
\hline & $\begin{array}{l}\text { Framing- } \\
\text { ham }\end{array}$ & $\begin{array}{l}\text { D:A:D } \\
\text { Reduced }\end{array}$ & $\begin{array}{l}\text { D:A:D } \\
\text { Full }\end{array}$ & $\begin{array}{l}p- \\
\text { value }\end{array}$ & $\begin{array}{l}\text { Framing- } \\
\text { ham }\end{array}$ & $\begin{array}{l}\text { D:A:D } \\
\text { Reduced }\end{array}$ & $\begin{array}{l}\text { D:A:D } \\
\text { Full }\end{array}$ & p-value & $\begin{array}{l}\text { Framing- } \\
\text { ham }\end{array}$ & $\begin{array}{l}\text { D:A:D } \\
\text { Reduced }\end{array}$ & $\begin{array}{l}\text { D:A:D } \\
\text { Full }\end{array}$ & $\begin{array}{l}p- \\
\text { value }\end{array}$ & \\
\hline $\begin{array}{l}\text { Male } \\
\text { (individuals) }\end{array}$ & $\begin{array}{l}1.37 \\
(108)\end{array}$ & $\begin{array}{l}0.48 \\
(54)\end{array}$ & $\begin{array}{l}0.48 \\
(50)\end{array}$ & 0.002 & $\begin{array}{l}13.40 \\
(4)\end{array}$ & $\begin{array}{l}2.35 \\
(69)\end{array}$ & $\begin{array}{l}2.49 \\
(68)\end{array}$ & 0.007 & $\begin{array}{l}\text { NC } \\
(0)\end{array}$ & $\begin{array}{l}6.96 \\
(17)\end{array}$ & $\begin{array}{l}6.95 \\
(14)\end{array}$ & 0.99 & $\begin{array}{l}31 \\
(1)\end{array}$ \\
\hline $\begin{array}{l}\text { Female } \\
\text { (individuals) }\end{array}$ & $\begin{array}{l}1.31 \\
(29)\end{array}$ & $\begin{array}{l}0.47 \\
(22)\end{array}$ & $\begin{array}{l}0.42 \\
(19)\end{array}$ & 0.06 & $\begin{array}{l}\text { NC } \\
(0)\end{array}$ & $\begin{array}{l}2.64 \\
(19)\end{array}$ & $\begin{array}{l}2.12 \\
(21)\end{array}$ & 0.934 & $\begin{array}{l}\text { NC } \\
(0)\end{array}$ & $\begin{array}{l}\text { NC } \\
(0)\end{array}$ & $\begin{array}{l}5.34 \\
(1)\end{array}$ & - & $\begin{array}{l}31 \\
(3)\end{array}$ \\
\hline $\begin{array}{l}\text { Smoking } \\
\text { (individuals) }\end{array}$ & $\begin{array}{l}2.10 \\
(46)\end{array}$ & $\begin{array}{l}0.58 \\
(19)\end{array}$ & $\begin{array}{l}0.57 \\
(15)\end{array}$ & 0.02 & $\begin{array}{l}12.67 \\
(3)\end{array}$ & $\begin{array}{l}2.90 \\
(36)\end{array}$ & $\begin{array}{l}2.50 \\
(37)\end{array}$ & 0.0001 & $\begin{array}{l}\text { NC } \\
(0)\end{array}$ & $\begin{array}{l}7.13 \\
(10)\end{array}$ & $\begin{array}{l}6.91 \\
(7)\end{array}$ & 0.733 & $\begin{array}{l}31 \\
(1)\end{array}$ \\
\hline $\begin{array}{l}\text { Non- } \\
\text { smoking } \\
\text { (individuals) }\end{array}$ & $\begin{array}{l}1.65 \\
(62)\end{array}$ & $\begin{array}{l}0.41 \\
(37)\end{array}$ & $\begin{array}{l}0.47 \\
(32)\end{array}$ & 0.003 & $\begin{array}{l}12.67 \\
(3)\end{array}$ & $\begin{array}{l}2.56 \\
(44)\end{array}$ & $\begin{array}{l}2.47 \\
(47)\end{array}$ & 0.0001 & $\begin{array}{l}\text { NC } \\
(0)\end{array}$ & $\begin{array}{l}7.11 \\
(10)\end{array}$ & $\begin{array}{l}7.43 \\
(7)\end{array}$ & 0.99 & $\begin{array}{l}31 \\
(1)\end{array}$ \\
\hline $\begin{array}{l}<40 \text { years } \\
\text { (individuals) }\end{array}$ & $\begin{array}{l}0.89 \\
(41)\end{array}$ & $\begin{array}{l}0.36 \\
(62)\end{array}$ & $\begin{array}{l}0.53 \\
(59)\end{array}$ & 0.02 & $\begin{array}{l}\text { NC } \\
(0)\end{array}$ & $\begin{array}{l}1.84 \\
(26)\end{array}$ & $\begin{array}{l}2.34 \\
(28)\end{array}$ & 0.312 & $\begin{array}{l}\text { NC } \\
(0)\end{array}$ & $\begin{array}{l}7.95 \\
(1)\end{array}$ & $\begin{array}{l}5.34 \\
(1)\end{array}$ & - & $\begin{array}{l}\text { NC } \\
0\end{array}$ \\
\hline $\begin{array}{l}\text { >40 years } \\
\text { (individuals) }\end{array}$ & $\begin{array}{l}1.38 \\
(88)\end{array}$ & $\begin{array}{l}0.66 \\
(14)\end{array}$ & $\begin{array}{l}0.62 \\
(10)\end{array}$ & 0.96 & $\begin{array}{l}13.40 \\
(3)\end{array}$ & $\begin{array}{l}2.59 \\
(63)\end{array}$ & $\begin{array}{l}2.67 \\
(61)\end{array}$ & $<0.0001$ & $\begin{array}{l}\text { NC } \\
(0)\end{array}$ & $\begin{array}{l}6.90 \\
(16)\end{array}$ & $\begin{array}{l}6.95 \\
(13)\end{array}$ & 0.90 & $\begin{array}{l}31.00 \\
(2)\end{array}$ \\
\hline $\begin{array}{l}\text { Diabetes } \\
\text { (individuals) }\end{array}$ & $\begin{array}{l}0.88 \\
(5)\end{array}$ & $\begin{array}{l}\text { NC } \\
(0)\end{array}$ & $\begin{array}{l}\text { NC } \\
(0)\end{array}$ & - & $\begin{array}{l}11.20 \\
(1)\end{array}$ & $\begin{array}{l}2.33 \\
(4)\end{array}$ & $\begin{array}{l}3.06 \\
(5)\end{array}$ & 0.421 & $\begin{array}{l}\text { NC } \\
(0)\end{array}$ & $\begin{array}{l}5.73 \\
(3)\end{array}$ & $\begin{array}{l}6.66 \\
(2)\end{array}$ & 0.540 & $\begin{array}{l}31 \\
(1)\end{array}$ \\
\hline Total CVR & Framingha & & $2.6 \%$ & & DAD (R) & & $2.30 \%$ & & $\mathrm{DAD}(\mathrm{F})$ & & $3.11 \%$ & & \\
\hline
\end{tabular}

Table 4. - Comparison of the algorithmic models stratified by body mass index (BMI).

\begin{tabular}{lllll} 
Model & Normo weight & Overweight & Obese & p-value \\
\hline Framingham & $2.38 \%$ & $3.47 \%$ & $2.21 \%$ & 0.661 \\
\hline D: A: D Reduced & $2.38 \%$ & $1.94 \%$ & 2.19 & 0.305 \\
\hline D: A: D Full & $3.35 \%$ & $2.48 \%$ & $2.96 \%$ & 0.381
\end{tabular}

Kruskal-Wallis Statistic; p-values $<0.05$

Table 5- Multivariate analysis of risk factors according to the Framingham and D:A:D algorithmic models. 
OR (IC95\%) unadjusted

\begin{tabular}{|c|c|c|c|c|c|c|c|c|c|c|c|}
\hline Variable & $\begin{array}{l}\text { Framingham } \\
(>10 \%)\end{array}$ & $\begin{array}{l}p- \\
\text { value }\end{array}$ & $\begin{array}{l}\text { D:A:D } \\
\text { reduced } \\
(>1 \%)\end{array}$ & p-value & $\begin{array}{l}\text { D:A:D } \\
\text { full } \\
(>1 \%)\end{array}$ & p-value & $\begin{array}{l}\text { Framingham } \\
(>10 \%)\end{array}$ & $\begin{array}{l}p- \\
\text { value }\end{array}$ & $\begin{array}{l}D: A: D \text { reduced } \\
(>1 \%)\end{array}$ & p-value & $\begin{array}{l}D: A: D \text { full } \\
(>1 \%)\end{array}$ \\
\hline Male & $\begin{array}{l}1.25(0.726- \\
2.15)\end{array}$ & 0.303 & $\begin{array}{l}1.44 \\
(1.01- \\
2.05)\end{array}$ & 0.059 & $\begin{array}{l}0.759 \\
(0.510- \\
1.26)\end{array}$ & 0.192 & $\begin{array}{l}0.689(0.121- \\
3.92)\end{array}$ & 0.675 & $2.47(0.69-6.08)$ & 0.06 & $5.28(1.3$ \\
\hline Female & $\begin{array}{l}0.581 \\
(0.225-1.05)\end{array}$ & - & $\begin{array}{l}0.738 \\
(0.519- \\
1.05)\end{array}$ & - & $\begin{array}{l}1.20 \\
(0.877- \\
1.64)\end{array}$ & - & - & - & - & - & - \\
\hline $\begin{array}{l}\text { Age }(>30 \\
\text { years) }\end{array}$ & $\begin{array}{l}1.05(1.01- \\
1.09)\end{array}$ & 0.601 & $\begin{array}{l}2.90 \\
(2.17- \\
3.89)\end{array}$ & $<0.0001$ & $\begin{array}{l}3.91 \\
(2.79- \\
5.49)\end{array}$ & $<0.0001$ & 82734463.245 & 0.999 & $\begin{array}{l}23.47 \text { (7.93- } \\
69.4)\end{array}$ & $<0.0001$ & 34.8 (8.0- \\
\hline $\begin{array}{l}\text { Cholesterol } \\
\text { (>200 mg/dL) }\end{array}$ & $\begin{array}{l}1.32(0.331- \\
5.29)\end{array}$ & 0.692 & $\begin{array}{l}1.32 \\
(1.04- \\
1.67)\end{array}$ & 0.033 & $\begin{array}{l}1.33 \\
(1.07- \\
1.64)\end{array}$ & 0.020 & $\begin{array}{l}0.688(0.125- \\
3.56)\end{array}$ & 0.637 & $\begin{array}{l}0.620(0.221- \\
1.73)\end{array}$ & 0.620 & $\begin{array}{l}0.62(0.16 \\
2.44)\end{array}$ \\
\hline $\begin{array}{l}\text { Triglycerides } \\
\text { (>150 mg/dL) }\end{array}$ & $\mathrm{NI}$ & - & $\begin{array}{l}2.44 \\
(1.34- \\
4.44)\end{array}$ & 0.003 & $\begin{array}{l}1.84 \\
(1.01- \\
3.36)\end{array}$ & 0.044 & $\begin{array}{l}1.88(0.316- \\
11.27)\end{array}$ & 0.468 & $\begin{array}{l}2.04(0.905- \\
4.61)\end{array}$ & 0.08 & $1.89\left(0.6^{\circ}\right.$ \\
\hline $\begin{array}{l}\mathrm{HDL}(<40 \\
\mathrm{mg} / \mathrm{dL})\end{array}$ & $\begin{array}{l}2.13(0.39- \\
11.37)\end{array}$ & 0.367 & $\begin{array}{l}0.594 \\
(0.262- \\
1.34)\end{array}$ & 0.209 & $\begin{array}{l}0.718 \\
(0.315- \\
1.63)\end{array}$ & 0.430 & $\begin{array}{l}0.853(0.08- \\
9.06)\end{array}$ & 0.468 & $\begin{array}{l}0.555(0.173- \\
1.77)\end{array}$ & 0.322 & $\begin{array}{l}0.409(0.1 \\
1.99)\end{array}$ \\
\hline $\begin{array}{l}\text { Blood pressure } \\
(>140 / 80 \\
\mathrm{mmHg})\end{array}$ & $\begin{array}{l}0.938 \\
(0.891- \\
0.981)\end{array}$ & 0.789 & $\begin{array}{l}0.614 \\
(0.545- \\
0.639)\end{array}$ & 0.429 & $\begin{array}{l}0.657 \\
(0.588- \\
0.733)\end{array}$ & 0.470 & 0.000 & 1.00 & 282770118.532 & 1.00 & $2441081^{\prime}$ \\
\hline $\begin{array}{l}\text { Current } \\
\text { smoker }\end{array}$ & $\begin{array}{l}0.583 \\
(0.140-2.43)\end{array}$ & 0.456 & $\begin{array}{l}1.42 \\
(1.12- \\
1.80)\end{array}$ & 0.004 & $\begin{array}{l}1.44 \\
(1.15- \\
1.79)\end{array}$ & 0.002 & $\begin{array}{l}0.387 \text { (0.07- } \\
2.08)\end{array}$ & 0.269 & $1.38(1.15-2.06)$ & 0.006 & $1.22(1.0\}$ \\
\hline Former smoker & $\mathrm{NI}$ & - & $\begin{array}{l}1.13 \\
(0.632- \\
2.03)\end{array}$ & 0.674 & $\begin{array}{l}1.24 \\
(0.686- \\
2.25)\end{array}$ & 0.472 & $\mathrm{NI}$ & - & $\begin{array}{l}1.08(0.462- \\
2.53)\end{array}$ & 0.856 & $\begin{array}{l}0.992(0 . \\
1.42)\end{array}$ \\
\hline Diabetes & $\mathrm{NI}$ & - & $\begin{array}{l}1.80 \\
(0.534- \\
5.95)\end{array}$ & 0.331 & $\begin{array}{l}2.34 \\
(0.629- \\
8.69)\end{array}$ & 0.193 & $\mathrm{NI}$ & - & $\begin{array}{l}1.60(0.343- \\
7.52)\end{array}$ & 0.548 & $\begin{array}{l}6.08(0.5 ! \\
6.70)\end{array}$ \\
\hline $\begin{array}{l}\text { Blood pressure } \\
\text { background }\end{array}$ & $\mathrm{NI}$ & - & $\mathrm{NI}$ & - & $\begin{array}{l}0.657 \\
(0.588- \\
0.733)\end{array}$ & 0.470 & $\mathrm{NI}$ & - & $\mathrm{NI}$ & - & $\begin{array}{l}0.491 \\
2.07)\end{array}$ \\
\hline $\begin{array}{l}\mathrm{CD} 4+(<350 \\
\left.\mathrm{cel} / \mathrm{mm}^{3}\right)\end{array}$ & $\mathrm{NI}$ & - & $\begin{array}{l}0.838 \\
(0.459- \\
1.53)\end{array}$ & 0.564 & $\begin{array}{l}0.878 \\
(0.476- \\
1.61)\end{array}$ & 0.675 & $\mathrm{NI}$ & - & $\begin{array}{l}0.824(0.362- \\
1.87)\end{array}$ & 0.645 & $\begin{array}{l}1.72(0.5 \\
5.44)\end{array}$ \\
\hline $\begin{array}{l}\text { Years with } \\
\text { cART }(>10)\end{array}$ & $\mathrm{NI}$ & - & $\mathrm{NI}$ & - & $\begin{array}{l}2.06 \\
(1.05- \\
4.04)\end{array}$ & 0.033 & $\mathrm{NI}$ & - & $\mathrm{NI}$ & - & $\begin{array}{l}0.968\left(0 .{ }^{\prime}\right. \\
3.42)\end{array}$ \\
\hline Total cART & $\mathrm{NI}$ & - & $\mathrm{NI}$ & - & $\begin{array}{l}1.82 \\
(0.960- \\
3.48)\end{array}$ & 0.065 & $\mathrm{NI}$ & - & $\mathrm{NI}$ & - & $\begin{array}{l}1.73\left(0.5^{\prime}\right. \\
5.69)\end{array}$ \\
\hline 2NRTI+1NNRTI & $\mathrm{NI}$ & - & $\mathrm{NI}$ & - & $\begin{array}{l}1.47 \\
(0.946- \\
2.27)\end{array}$ & - & $\mathrm{NI}$ & - & $\mathrm{NI}$ & - & - \\
\hline 2INTR+2IP & $\mathrm{NI}$ & - & $\mathrm{NI}$ & - & $\begin{array}{l}0.870 \\
(0.650- \\
1.00)\end{array}$ & - & $\mathrm{NI}$ & - & $\mathrm{NI}$ & - & - \\
\hline
\end{tabular}

HDL: high-density lipoprotein; CART: highly active antiretroviral therapy; NRTI (nucleoside reverse transcriptase inhibitor); NNRTI (non-nucleoside reverse transcriptase inhibitor) IP (protease inhibitor); NC: variables not calculated due to a small number of individuals in the stratum; NI: Variables not included in the model; $p$-values $<0.05$ after multivariate analysis are shown in bold.

\section{Supplementary Files}

This is a list of supplementary files associated with this preprint. Click to download.

- supplementarymaterial.docx

OR (IC95\%) adjusted by age and sex 